\title{
PENDAMPINGAN PEMBUATAN ALAT PERMAINAN EDUKATIF TOPIK EKOLOGI BERBASIS STEAM PADA KELOMPOK GURU PAUD KECAMATAN TEMAYANG KABUPATEN BOJONEGORO
}

\author{
Muhamad Imaduddin ${ }^{1}$, Latifatul Nihayati ${ }^{1}$, Toyib Wahyu Nugroho ${ }^{1}$, Wisnu Bayu Murti ${ }^{1}$, \\ Latifatus Sa'adah ${ }^{1}$, Desy Kurniasari ${ }^{1}$ \\ ${ }^{1}$ Institut Agama Islam Negeri Kudus, Kudus, Indonesia \\ imad@iainkudus.ac.id
}

\begin{abstract}
Abstrak: Implementasi STEAM (Science, Technology, Engineering, Arts, and Mathematics), yang merupakan salah satu pendekatan yang banyak dikembangkan oleh berbagai negara, masih belum banyak dipahami oleh banyak guru, termasuk pada kelompok guru PAUD PKG SMART. Tujuan kegiatan pengabdian kepada masyarakat (PkM) ini adalah untuk meningkatkan kompetensi pedagogik guru melalui keterampilan dalam memproduksi Alat Permainan Edukaitf (APE). Kajian ini akan memaparkan bagaimana pelaksanaan proses pendampingan guru dalam memproduksi APE, serta bagaimana performa dan implemetasi guru dengan menggunakan APE topik ekologi dengan pendekatan STEAM. PkM ini merupakan aktivitas pendampingan dalam bentuk pembelajaran yang mengacu pada model pembelajaran berbasis proyek dengan tahapan utama yaitu launching, monitoring, dan evaluating. Peserta kegiatan pengabdian kepada masyarakat ini terdiri dari 90 guru yang terdiri dari 30 guru Pos PAUD, 30 guru Kelompok Belajar, dan 30 guru TK di wilayah kecamatan Temayang, kabupaten Bojonegoro, Jawa Timur. Pengumpulan data melalui dokumentasi, observasi produk dan performa kelompok, serta wawancara kelompok. Target model produk yang diharapkan adalah kotak yang utamanya difungsikan untuk mengajarkan konsep ekosistem darat dan perairan. Keberhasilan program ini ditunjukkan dari (1) terlaksananya tahapan pendampingan, (2) diperolehnya produk APE yang sesuai dengan target yang ditentukan tim, (3) performa guru sudah menunjukkan penambahan wawasan dalam mengimplementasikan APE dan memodifikasi APE dengan pendekatan STEAM dan (4) respon positif ditunjukkan dengan antusiasme guru
\end{abstract}

Kata Kunci: alat permainan edukatif, STEAM, pendampingan, topik ekologi

\begin{abstract}
The implementation of STEAM (Science, Technology, Engineering, Arts, and Mathematics), which is one of the approaches developed by many countries, is still not widely understood by many teachers, including early childhood teachers in PKG SMART. The purpose of this community service program is to improve teachers' pedagogical competence through skills in producing Educational Game Tools (EGT). This article will describe how the teachers' mentoring process is implemented in producing EGT, as well as how teachers' performance and practices using EGT on the topic of ecology with the STEAM approach. This program is a mentoring activity that refers to a project-based learning model following three stages; aunching, monitoring, and evaluating. Participants consist of 90 early childhood teachers in Temayang sub-district, Bojonegoro regency, East Java. Data was collected through documentation, product observation and group performance, and group interviews. The expected product model is a box to teach the concept of terrestrial and aquatic ecosystems. The effectivity of this program is shown from (1) the implementation of the mentoring stages, (2) the produced EGT meets the specificationsset by the team, (3) teachers' performance is better in implementing EGT and modifying EGT with the STEAM approach and (4) positive responses are evident in the teachers' enthusiasm.
\end{abstract}

Keywords: educational game tools, STEAM, mentoring, ecological topics

\section{Pendahuluan}

Sains menjadi komponen yang makin krusial dalam pengembangan kurikulum pendidikan anak di berbagai negara (Asoko, 2000). Hal ini sejalan dengan makin pesatnya ilmu 
pengetahuan dan teknologi yang ada saat ini. Sains menjadi peran penting hingga perlu diajarkan sejak usia dini. Meskipun sains yang diajarkan kepada anak tidak dapat digunakannya sebagai bekal anak untuk berkarir menjadi saintis, sains tetap saja erat kaitannya dengan keseharian anak sebagai warga negara. Sains untuk anak usia dini juga penting untuk diajarkan untuk pembentukan konsep saing pada jenjang selanjutnya.

Kondisi yang cukup memperihatinkan berkaitan dengan literasi anak di Indonesia. PISA (Programme for International Student Assessment) yang menilai kemampuan anak usia 15 tahun di bidang matematika, sains, dan membaca menunjukkan bahwa skor membaca Indonesia ada di peringkat 72 dari 77 negara, lalu skor matematika ada di peringkat 72 dari 78 negara, dan skor sains ada di peringkat 70 dari 78 negara (The OECD Programme for International Student Assessment, 2019). Hal ini menjadi momok awal berkaitan dengan daya saing Indonesia di masa mendatang. Analisis PISA menunjukkan bahwa masih banyaknya proses pendidikan di Indonesia yang harus diperbaiki bahkan sejak dini. Kondisi ini menunjukkan masih belum optimalnya dorongan sekolah dalam melatih keterampilan berpikir tingkat tinggi. Proses pendidikan masih sarat dengan berfokus pada ingatan, pemahaman, dan penerapan yang merupakan fase berpikir tingkat awal. Pendidikan masih belum banyak memberikan ruang untuk mencapai kemampuan analisis, evaluatif, dan kreatif. Kondisi ini harus segera diatasi karena perkembangan negara terletak pada kualitas Sumber Daya Manusia (SDM) yang ada bukan hanya dari alamnya saja. Dengan demikian, sudah tentulah peningkatan kualitas pendidikan harus dimulai dari jenjang pendidikan anak usia dini.

STEAM (Science, Technology, Engineering, Arts, and Mathematics) menjadi fenomena pendidikan yang telah dikembangkan oleh berbagai negara. STEAM dianggap sebagai komponen penting yang tepat untuk mempersiapkan generasi yang memiliki literasi dan daya saing di bidang sains dan teknologi. Indonsia juga mengarahkan kurikulum pendidikannya dengan menekankan pada aspek-aspek STEAM yang relevan dengan kebutuhan industri. Hal ini sebagaimana tertuang dalam peta jalan "Making Indonesia 4.0" (Kementerian Perindustrian Republik Indonesia, 2018). Pendekatan ini merupakan pendekatan multidisipliner yang tidak terpisahkan untuk memecahkan beragam permasalahan sehari-hari (Dejarnette, 2018; Imaduddin, 2017; Imaduddin \& Zuhaida, 2019; Sutaphan \& Yuenyong, 2019).

Salah satu permasalahan yang erat di kehidupan anak adalah permasalahan lingkungan. Bagaimana anak usia dini mengenal dengan baik lingkungannya adalah titik awal membentuk sikap sadar terhadap kelestarian lingkungan. Interaksi individu dengan lingkungan ini dipelajari dalam kajian ilmu yang dinamakan ekologi (Encyclopædia Britannica, 2020). Mengajarkan anak usia dini (AUD) tentang lingkungan menjadi hal yang penting untuk dilaksanakan. Peran pendidikan ini tentunya merupakan tugas orang-orang dewasa yang ada di sekitar anak, baik itu keluarga maupun pihak sekolah. Oleh karena itu, pendidikan pada level AUD perlu menjadi sorotan apakah sudah mulai untuk mengimplementasikan STEAM sebagai salah satu pendekatannya atau belum.

Didasarkan pada diskusi awal dengan kelompok guru pada Pusat Kegiatan Gugus (PKG) SMART kecamatan Temayang, kabupaten Bojonogoro, Jawa Timur, diketahui bahwa belum banyak guru yang memahami pendekatan ini. Guru juga mengajarkan sains dengan pandangan 
behavioristik dan drill menggunakan lembar kerja. Implementasi pembelajaran pada level AUD, terutama di bidang sains menjadi sorotan karena tidak diajarkan dengan cara yang konstruktif sebagaimana arah pembelajaran STEM ataupun STEAM (Roberts, 2016; Taylor, 2016). Pembelajaran pada level AUD juga masih terkendala dengan minimnya alat permainan edukatif (APE) yang dimanfaatan oleh guru untuk mengajarkan sains. APE dianggap penting untuk pembelajaran karena mampu menarik minat anak dalam belajar. Cara belajar anak yang paling tepat adalah dengan bermain (Montessori, 2013). Kunci perkembangan anak-anak sangat tergantung pada penyediaan lingkungan yang mendukung untuk mengembangkan bakatnya. Dengan demikian, tujuan dari kegiatan Pengabdian kepada Masyarakart (PkM) ini adalah untuk meningkatkan kompetensi pedagogik guru PAUD melalui keterampilan dalam memproduksi APE. Kajian ini akan memaparkan bagaimana pelaksanaan proses pendampingan guru dalam memproduksi APE, serta bagaimana performa dan implemetasi guru dengan menggunakan APE topik ekologi dengan pendekatan STEAM.

\section{Metode}

Kegiatan pengabdian kepada masyarakat ini dilaksanakan melalui aktivitas pendampingan dalam bentuk pembelajaran yang mengacu pada model pembelajaran berbasis proyek atau Project-Based Learning yang dimodifikasi dari Meli (2020). Model ini terdiri dari tiga tahapan utama yaitu launching, monitoring, dan evaluating sebagaimana diperlihatkan pada Tabel 1.

Tabel 1. Tahapan kegiatan pendampingan pembuatan APE topik ekologi berbasis STEAM

\begin{tabular}{|c|c|c|c|}
\hline No & Tahapan & Detail Kegiatan & Tujuan \\
\hline 1 & Launching & $\begin{array}{l}\text { - Familiarization } \rightarrow \text { Memperkenalkan } \\
\text { 1) Paparan tentang pembelajaran yang } \\
\text { konstruktif dengan pendekatan STEAM } \\
\text { (Imaduddin, 2017) } \\
\text { 2) Demonstrasi beberapa contoh pembelajaran } \\
\text { STEAM untuk anak usia dini } \\
\text { - Topic Selection } \rightarrow \text { Memilih topik dan } \\
\text { menentukan contoh APE untuk digunakan sebagai } \\
\text { proyek target pada kegiatan pendampingan. } \\
\text { Penugasan dilakukan sebelum kegiatan } \\
\text { workshop diselenggarakan yaitu berupa persiapan } \\
\text { alat dan bahan, serta materi untuk target proyek. } \\
\text { - Identifying a driving question } \rightarrow \text { "Bagaimana } \\
\text { membuat APE berbasis STEAM dengan } \\
\text { memanfaatkan barang bekas (kardus bekas)" }\end{array}$ & $\begin{array}{l}\text { 1) Diperoleh } \\
\text { pemahaman } \\
\text { kelompok guru } \\
\text { tentang } \\
\text { pembelajaran } \\
\text { konstruktivisme } \\
\text { untuk anak usia dini } \\
\text { dengan pendekatan } \\
\text { STEAM } \\
\text { 2) Kesiapan kelompok } \\
\text { untuk melaksanakan } \\
\text { target proyek yang } \\
\text { dipilih pada kegiatan } \\
\text { pendampingan }\end{array}$ \\
\hline 2 & Monitoring & $\begin{array}{l}\text { - Group formation } \rightarrow \text { Guru PAUD dikelompokkan } \\
\text { menjadi } 10 \text { kelompok yang masing-masing terdiri } \\
\text { dari } 9 \text { orang } \\
\text { - Organizing } \rightarrow \text { Kelompok guru diberikan target } \\
\text { waktu selama } 4 \text { jam dengan difasilitasi tim dan } \\
\text { model target APE } \\
\text { - Report sessions } \rightarrow \text { Kelompok guru melaporkan } \\
\text { penyelesaian target pembuatan APE }\end{array}$ & $\begin{array}{l}\text { Diperoleh APE } \text { topik } \\
\text { ekologi berbasis STEAM } \\
\text { sesuai dengan target } \\
\text { model }\end{array}$ \\
\hline
\end{tabular}




\begin{tabular}{|c|c|c|c|}
\hline No & Tahapan & Detail Kegiatan & Tujuan \\
\hline 3 & Evaluating & $\begin{array}{l}\text { - End-product presentation } \rightarrow \text { Kelompok guru } \\
\text { diberikan kesempatan untuk menyajikan praktik } \\
\text { singkat pemanfaatan APE untuk pembelajaran } \\
\text { siswa } \\
\text { - Peer- and self-assessment } \rightarrow \text { Masing-masing } \\
\text { anggota kelompok dan kelompok lainnya } \\
\text { memberikan penilaian dan saran untuk performa } \\
\text { kelompok } \\
\text { - Reflection } \rightarrow \text { Kelompok guru merefleksi APE } \\
\text { yang dibuat dan memperbaiki sesuia dengan saran }\end{array}$ & $\begin{array}{l}\text { Diperoleh perbaikan APE } \\
\text { dan kesesuaian untuk } \\
\text { diimplementasikan oleh } \\
\text { guru }\end{array}$ \\
\hline
\end{tabular}

Peserta kegiatan pengabdian kepada masyarakat ini terdiri dari 90 guru yang terdiri dari 30 guru Pos PAUD (PP), 30 guru Kelompok Belajar (KB), dan 30 guru Taman Kanak-kanak (TK) di wilayah kecamatan Temayang, kabupaten Bojonegoro, Jawa Timur yang memiliki variasi durasi pengalaman mengajar. Pengumpulan data pada aktivitas pengabdian ini melalui dokumentasi, observasi produk dan performa kelompk, serta wawancara kelompok. Dokumentasi dilaksanakan pada setiap tahapan kegiatan dan ekspresi para peserta. Observasi produk menggunakan rubrik sederhana dengan komponen dan kriteria sebagaimana ditunjukkan pada Tabel 2.

Tabel 2. Kriteria penskoran produk pada pendampingan pembuatan APE

\begin{tabular}{|c|c|c|}
\hline No & Kriteria & Skor \\
\hline 1 & $\begin{array}{l}\text { Kesesuian } \\
\text { produk }\end{array}$ & $\begin{array}{l}3=\text { Jika produk yang dihasilkan sesuai dengan bentuk yang ditargetkan } \\
2=\text { Jika produk yang dihasilkan hampir selesai }(>50 \%) \text { sesuai bentuk } \\
\text { yang ditargetkan } \\
1=\text { Jika produk yang dihasilkan tidak sesuai atau belum mencapai } 50 \% \\
\text { bentuk yang diharapkan }\end{array}$ \\
\hline 2 & $\begin{array}{l}\text { Presentasi } \\
\text { produk }\end{array}$ & $\begin{aligned} 3= & \text { Jika kelompok dapat mempraktikkan pemanfaatan produk APE untuk } \\
& \text { pengajaran berkaitan dengan ekologi dan masing-masing aspek } \\
& \text { STEAM (Science, Technology, Engineering, Arts, and Mathematics) } \\
2= & \text { Jika kelompok belum mempraktikkan pemanfaatan produk APE untuk } \\
& \text { pengajaran secara keseluruhan } \\
1= & \text { Jika kelompok memanfaatkan produk APE untuk mengajar dengan } \\
& \text { tema yang melenceng dari apa yang targetkan }\end{aligned}$ \\
\hline 3 & $\begin{array}{l}\text { Kreativitas } \\
\text { dalam } \\
\text { modifikasi } \\
\text { produk }\end{array}$ & $\begin{aligned} 3= & \text { Jika kelompok memberikan modifikasi produk tanpa meninggalkan } \\
& \text { aspek yang ditargetkan } \\
2= & \text { Jika kelompok memberikan modifikasi produk tetapi ada aspek topik } \\
& \text { ekologi terintegrasi STEAM yang hilang, atau kelompok tidak } \\
& \text { melakukan modifikasi pada produknya } \\
1= & \text { Jika modifikasi kelompok tidak memunculkan aspek STEAM yang } \\
& \text { ditargetkan }\end{aligned}$ \\
\hline
\end{tabular}

Target model produk yang diharapkan adalah kotak yang utamanya difungsikan untuk mengajarkan konsep ekosistem darat dan perairan. Ada beberapa spesifikasi yang diharapkan pada APE yang ditargetkan yaitu (1) adanya gambar situasi yang menunjukkan kondisi perairan dan daratan, (2) Adanya ragam figur binatang yang masuk pada kategori hewan darat dan hewan air, (3) kotak yang bisa dibuka dan ditutup, serta memiliki pop-up pada bagian dalam kotak. Pop-up bisa dimodifikasi sesuai dengan kebutuhan. Target model yang digunakan pada aktivitas pendampingan ini sebagaimana diperlihatkan pada Gambar 1. 


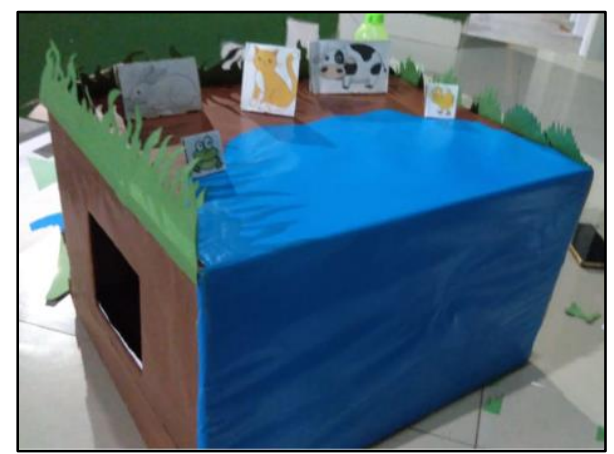

Tampak luar APE

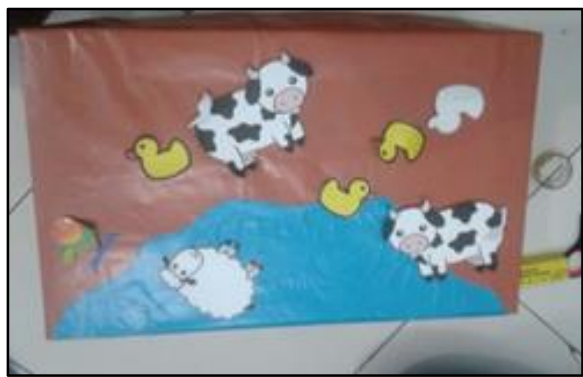

Tampak atas APE dan beberapa figur binatang

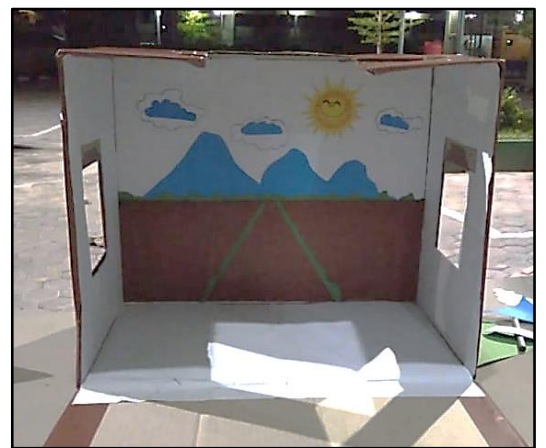

Tampak dalam APE

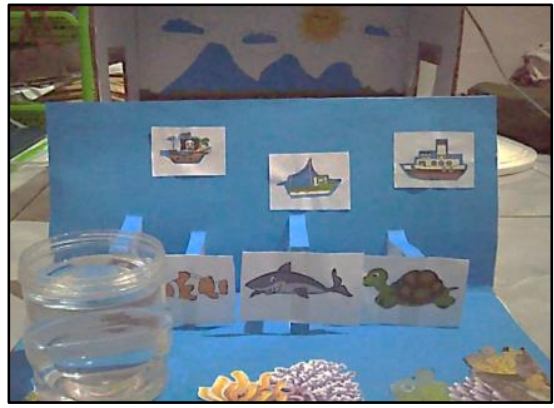

Tampak dalam APE hasil pop-up (menunjukkan dua kondisi ekosistem)

Gambar 1. Target model APE topik ekologi berbasis STEAM

Wawancara dilakukan pada perwakilan kelompok untuk mengetahui kesan kelompok guru dalam aktivitas yang diselenggarakan serta peluang untuk memanfaatkan APE dalam pembelajaran anak usia dini. Analisis secara deskriptif digunakan untuk menggambarkan pelaksanaan proses pendampingan, kondisi produk peserta, serta dominasi kesan yang muncul pada kegiatan. Analisis keberhasilan dari kegiatan ini ditunjukkan dari (1) pelaksanaan setiap tahapan kegiatan, (2) kondisi produk APE yang dihasilkan, (3) performa guru dalam mengujicoba pembelajaran dengan APE topik ekologi berbasis STEAM, dan (4) kesan yang diberikan oleh peserta terhadap kegiatan pendampingan.

\section{Hasil dan Pembahasan}

Ekologi merupakan ilmu yang mempelajari bagimana organisme-organisme hidup saling berinteraksi dan berhubungan timbal balik dengan lingkungannya (Encyclopædia Britannica, 2020). Ekologi penting untuk dipelajari karena menunjukkan bagaimana perubahan lingkungan mempengaruhi kelangsungan hidup makhluk. Misalnya, ketika terjadi polusi, akan ada beberapa hewan yang mati karena tidak bisa bertahan hidup. Mempelajari ekologi sejak dini menjadikan anak lebih peka dan dapat meyakinkan mereka di masa mendatang untuk dapat melestarikan, melindungi, dan menjaga lingkungan serta semua komponen ekosistem pendukungnya.

Didasarkan penjaringan data melalui diskusi dengan kelompok guru yang ada, aktivitas pengajaran sains pada anak usia dini masih didominasi kegiatan mengerjakan lembar kerja. Aktivitas sentra juga belum optimal dilaksankan pada masing-masing lembaga tempat mereka 
bertugas. Pada kegiatan pendampingan ini, kegiatan dibagi menjadi dua aktivitas yaitu aktivitas minds-on dan aktivitas hands-on. Kegiatan hands-on memainkan peran yang penting untuk memahami arti pada sebenarnya yang diharapkan (Hofstein, Kipnis, \& Kind, 2008) dalam kegiatan pendampingan ini, yaitu peningkatan keterampilan pedagogik guru PAUD dalam mengimplementasikan pembelajaran dengan pendekatan STEAM. Memadukan aktivitas handson dan minds-on membantu mengembangkan kesadaran ilmiah (Acharya, 2018). Oleh karena itu, pada aktivitas pendampingan ini kegiatannya dilaksanakan dengan memadukan keduanya. Guru didampingi untuk praktik membuat alat permainan edukatif (APE).

Alat permainan edukatif merupakan sarana yang menstimulus aktivitas anak untuk mempelajarai sesuatu tanpa menyadarinya, baik menggunakan teknologi modern maupun sederhana, bahkan bersifat tradisional. Alat permainan edukatif juga merupakan alat yang dapat meningkatkan pengetahuan dan pemahaman anak tentang sesuatu. Alat permainan adalah semua alat bermain yang digunakan anak untuk memenuhi naluri bermainnya dan memiliki berbagai macam sifat seperti bongkar pasang, mengelompokkan, memadukan, mencari padanannya, merangkai, membentuk, mengetok, menyempurnakan suatu desain, atau menyusun sesuai bentuk utuhnya (Sudono, 2000). Pada dasarnya anak memang berada dalam masa bermain. Maka yang dibutuhkan bukanlah alat pembelajaran atau alat peraga, melainkan alat permainan untuk mendukung kegiatan bermainnya. Dari pengertian tersebut dapat dikatakan bahwa APE merupakan alat permainan yang mempunyai nilai-nilai edukatif, yaitu dapat mengembangkan segala aspek dan kecerdasan yang ada pada diri anak.

Kegiatan pendampingan pembuatan APE dilaksanakan dengan tiga tahapan sebagaimana ditunjukkan pada Gambar 2. Sebelum aktivitas pendampingan secara tatap muka, kelompok guru telah diberikan tugas untuk mempersiapkan alat dan bahan yang dibutuhkan untuk membuat target model APE topik ekologi berbasis STEAM. Tahap launching merupakan tahapan aktivitas minds-on yang berupaya memberikan kesadaran kepada guru terkait teori praktik pembelajaran sains dan matematika untuk anak usia dini yang seharusnya dilaksanakan secara konstruktif. Cara pandang pendidik diarahkan untuk menjadi pendidik yang konstruktivis yang memfasilitasi siswa untuk mengkonstruksi pengetahuan anak melalui proses yang dinamis dan interaktif (Chaille \& Britain, 2003). Kelompok guru diberikan contoh sederhana praktik pembelajaran konstruktif dengan alat peraga yang sudah disediakan oleh tim yaitu, peraga pembuatan grafik sederhana menggunakan bekas banner, serta peraga energi potensial dengan memanfaatkan bidang miring dari kayu bekas. Kegiatan demonstrasi ditunjukkan untuk menggeser paradigma pola pembelajaran sains ataupun matematika yang biasa dikerjakan oleh guru PAUD agar lebih bersifat konstruktif. Pada tahap ini, diperoleh kesiapan guru untuk melaksanakan target proyek yaitu pembuatan alat permainan edukatif dengan pendekatan STEM.

Pada tahap launching ditunjukkan target model proyek untuk tahap berikutnya, serta merumuskan target kegiatan untuk membuat APE berbasis STEAM dengan memanfaatkan barang bekas (kardus bekas). APE ini utamanya difungsikan untuk mengajarkan topik ekologi, atau dalam hal pembelajaran PAUD adalah membedakan hewan darat, air tawar, dan air laut. Melanjutkan tahapan ini, pada tahap monitoring peserta dikelompokkan menjadi sepuluh 
kelompok yang masing-masing terdiri dari sembilan guru. Pengelompokkan sesuai dengan keinginan dan koordinator peserta dari pihak guru.

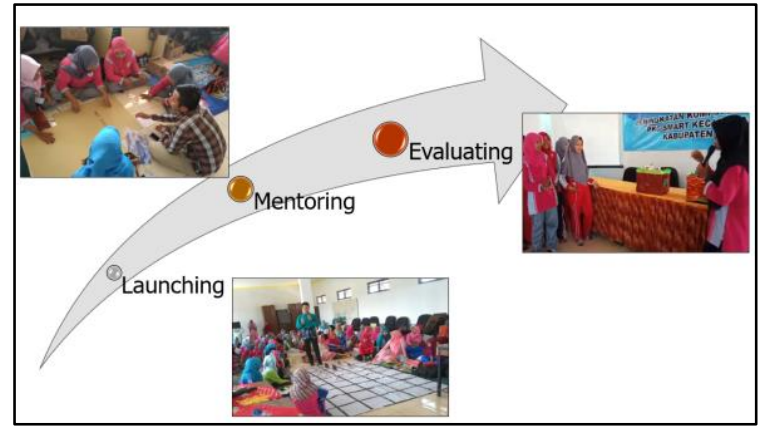

Gambar 2. Rangkaian kegiatan pendampingan untuk menghasilkan APE topik ekologi

Pada proses monitoring, guru terlihat antusias dan aktif untuk mengerjakan pembuatan APE dengan didampingi oleh tim. Keseluruhan kelompok menyelesaikan target APE model selama kurang lebih empat jam. Masing-masing kelompok didampingi oleh satu orang fasilitator yang memberikan arahan desain dasar APE, serta kebutuhan alat dan bahan.

Pada proses evaluating, kelompok guru diminta untuk mencoba mempraktikkan pembelajaran dengan menggunakan APE yang telah dibuatnya. Tim PkM, serta anggota kelompok dan kelompok lainnya memberikan penilaian dan saran untuk performa kelompok. Hasil performa produk, penampilan kelompok, serta modifikasi pada produk yang dibut diskor menggunakan rubrik sederhana. Hasil rekapitulias skor ditunjukkan pada Tabel 3.

Tabel 3. Rekapitulasi skor performa produk dan implementasinya oleh kelompok guru

\begin{tabular}{lcccc}
\hline No & Kelompok & $\begin{array}{c}\text { Skor } \\
\text { Kesesuian } \\
\text { Produk }\end{array}$ & $\begin{array}{c}\text { Presentasi } \\
\text { produk }\end{array}$ & $\begin{array}{c}\text { Kreativitas dalam } \\
\text { modifikasi produk }\end{array}$ \\
\hline 1 & I & $3 / 3$ & $3 / 3$ & $3 / 3$ \\
\hline 2 & II & $3 / 3$ & $2 / 3$ & $2 / 3$ \\
\hline 3 & III & $3 / 3$ & $3 / 3$ & $3 / 3$ \\
\hline 4 & IV & $3 / 3$ & $3 / 3$ & $3 / 3$ \\
\hline 5 & V & $3 / 3$ & $3 / 3$ & $3 / 3$ \\
\hline 6 & VI & $3 / 3$ & $3 / 3$ & $3 / 3$ \\
\hline 7 & VII & $3 / 3$ & $3 / 3$ & $3 / 3$ \\
\hline 8 & VIII & $3 / 3$ & $3 / 3$ & $3 / 3$ \\
\hline 9 & IX & $1 / 3$ & $2 / 3$ & $1 / 3$ \\
\hline 10 & X & $3 / 3$ & $3 / 3$ & $3 / 3$ \\
\hline & Rata-rata & $2,8 / 3$ & $2,8 / 3$ & $2,7 / 3$ \\
\hline
\end{tabular}

Hasil menunjukan masih ada beberapa performa yang tidak menunjukkan target pembelajaran yang holistik pada masing-masing aspek STEAM yang diajarkan. Meskipun demikian, jika ditinjau dari produk yang dihasilkan serta bagaimana guru mencoba mempraktikkannya dalam pembelajaran, secara keseluruhan dapat diketahui bahwa kegiatan pendampingan ini menghasilkan output yang baik dan memberikan wawasan kepada guru untuk lebih kreatif dalam memproduksi APE, serta mengajarkan STEAM yang integratif dan konstruktif di kelas. Kelompok guru bahkan dapat memodifikasi produk yang ditargetkan. Hal 
ini sebagaimana diperlihatkan pada Gambar 3. Catatan penting terkait dengan modifikasi oleh kelompok guru mencakup:

1. Pop-up pengajaran abjad;

2. Pop-up pengajaran pengajaran membilang (1-10);

3. Pengajaran warna;

4. Pegantar lagu untuk mengajar dengan APE;

5. Modifikasi jenis hewan, semisal kupu-kupu, gurita, dan bintang laut;

6. Modifikasi bentuk pola dan tata letak item pada kotak;

7. Modifikasi setting ekosistem, contoh set kampung nelayan;

8. Pengenalan tanaman buah.
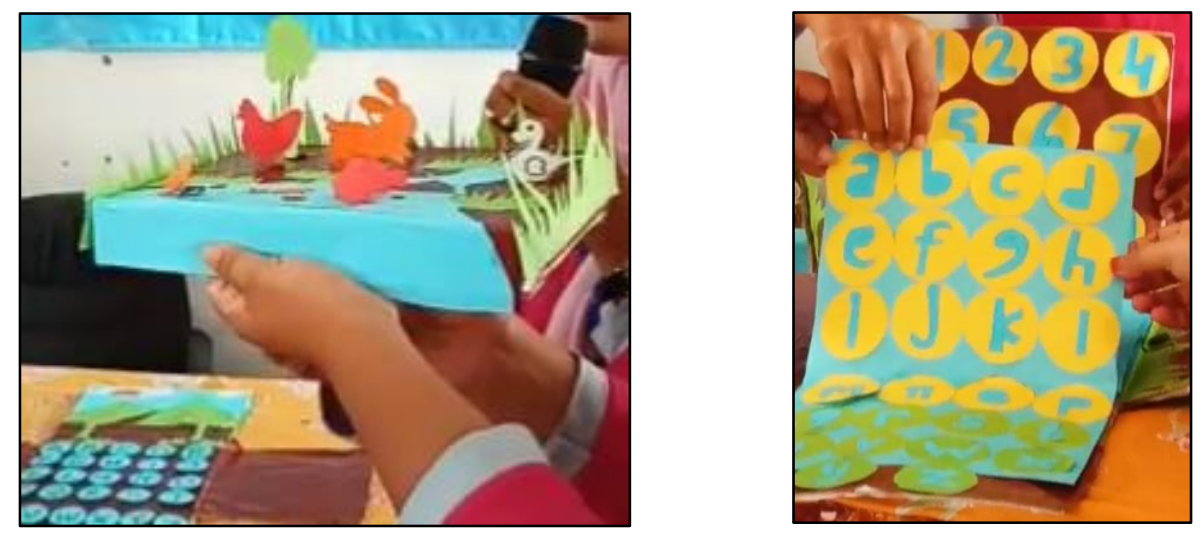

Gambar 3. Beberapa hasil modifikasi dari peserta pendampingan

Target model awal yang diharapkan dibuat oleh guru adalah APE yang diberi nama Magical Eco-Box. Magical ECo-Box adalah sebuah kotak yang terbuat dari kertas karton keras yang terdiri dari empat bagian yaitu tutup kotak, tubuh kotak, pop-up dalam kotak, dan komponen lingkungan yang dapat digerakkan dengan maemanfaatkan media magnet. Media ini dapat digunakan untuk merangsang keterampilan anak usia dini terutama keterampilan kognitif. Selain itu, keterampilan lain seperti nilai moral dan agama, bahasa, seni, dan emosi sosial dapat dipupuk tergantung pada bagaimana menyajikan magical eco-box sebagai media pembelajaran untuk anak usia dini.

Tujuan utama dari Magical Eco-Box adalah untuk mengembangkan kesadaran lingkungan anak usia dini. Di era modern ini, banyak orang tidak menyadari bahwa mereka benar-benar membutuhkan alam untuk hidup mereka. Orang dewasa sering tidak memberi kesempatan bagi anak-anak untuk mengeksplorasi minat mereka terhadap alam. Ini berdampak pada kesadaran lingkungan secara tidak langsung. Karena itu, kami mencoba untuk memperkenalkan sifat yang terdiri dari beberapa komponen ekologis melalui media yang menarik untuk anak-anak.

Magical ECo-Box mengilustrasikan pemandangan dari daratan, danau dan laut melalui media yang dapat dimainkan oleh anak-anak. Media ini dapat diterapkan untuk mengajarkan STEAM (Science, Technology, Engineering, Arts, and Mathematics) untuk anak-anak. Pembelajaran sains berkaitan dengan bagaimana anak memahami lingkungan (daratan, danau, dan lautan), mempelajarai teknologi dan teknik berkaitan dengan penggunaan magnet yang 
digunakan untuk bermain dalam Magical Eco-Box. Di sisi lain, seni dapat diajarkan dengan membuat contoh figur hewan, matematika juga dapat dipelajari dalam bentuk penghitungan, klasifikasi, dan pengukuran. Dengan demikian, Magical Eco-Box dapat menjadi media multifungsi yang efektif untuk mendukung kesadaran lingkungan di berbagai usia anak-anak. Adapun target awal dan bentuk contoh implementasi STEAM yang difokuskan pada kegiatan ini ditunjukkan pada Tabel 4 .

Tabel 4. Implementasi APE dengan pendekatan STEAM untuk anak usia dini

\begin{tabular}{|c|c|}
\hline Kompenen & Deskripsi Kegiatan \\
\hline Science & $\begin{array}{l}\text { Kegiatan ini dapat digunakan untuk mendeskripsikan tentang habitat hewan } \\
\text { melalui cerita tentang interaksi hewan dalam ekosistem). Magnet difungsikan } \\
\text { sebagai alat untuk menggeser posisi figur (membuatnya bergerak). Pada } \\
\text { akhirnya, anak-anak dapat lebih sadar tentang pelestarian lingkungan. Saat } \\
\text { berusia } 5 \text { - } 6 \text { tahun, anak juga dapat diminta untuk menghias patung-patung } \\
\text { binatang di habitat yang sesuai. }\end{array}$ \\
\hline $\begin{array}{l}\text { Technology } \\
\text { and } \\
\text { Enggineering }\end{array}$ & $\begin{array}{l}\text { APE ini dapat digunakan untuk mengajarkan perbedaan benda magnetik dan } \\
\text { benda non-magnet (benda yang dapat ditarik oleh magnet dan yang tidak dapat } \\
\text { ditarik oleh magnet). }\end{array}$ \\
\hline Arts & Contoh gambar hewan dapat dimodifikasi dengan kreasi gambar anak. \\
\hline Mathematics & $\begin{array}{l}\text { Classification (Klasifikasi): Tokoh-tokoh binatang dapat diberikan kepada } \\
\text { anak dan mereka diminta untuk mendekorasi binatang sesuai yang mereka } \\
\text { inginkan. Setelah itu, periksa posisi tokoh binatang di habitat yang sesuai. Anak- } \\
\text { anak diminta untuk mengklasifikasikan binatang berdasarkan habitat (di dalam } \\
\text { atau di luar air). } \\
\text { Counting (Menghitung): Anak diminta untuk menghitung jumlah bidatang } \\
\text { pada masing-masing habitat pada APE. } \\
\text { Measuring (Mengukur): Sosok binatang diurutkan berdasarkan ukurannya. }\end{array}$ \\
\hline
\end{tabular}

Dari serangkaian kegiatan, diketahui bahwa guru antusias untuk menghasilkan produk, serta memberikan respon positif dari ekspresi dan hasil wawancara yang dilaksanakan oleh tim. Guru juga menunjukkan optimisnya pemanfaatan APE untuk pembelajaran di kelas mereka nantinya. Beberapa ungkapan dari para guru terhadap pendampingan yang diberikan ditunjukkan pada pernyataan guru berikut ini.

Guru A: "Pelatihannya asyik dan menyenangkan, sampai tidak terasa waktunya ternyata sudah mau selesai"

Guru B: "Tidak ada kesulitan yang berarti dan senang"

Guru C: "Kerjanya bergantian dengan teman-teman sekelompok"

Guru D: "Kelompok saya membuat APE sejumlah 3"(melebihi jumlah yang ditugaskan)

Guru E: "Lagi seru ..." (sembari terus mengerjakan pembuatan APE secara berkelompok)

Berdasarkan rangkaian kegiatan yang dilaksanakan, dapat diketahui keberhasilan dari pendampingan ini mencakup (1) terlaksananya tahapan launching, monitoring, dan evaluating; (2) diperoleh produk APE yang dibuat kelompok dengan durasi yang singkat; (3) performa guru sudah menunjukkan penambahan wawasan dalam mengimplementasikan APE dan memodifikasi APE dengan pendekatan STEAM; (4) Respon positif ditunjukkan dengan 
antusiasme guru dan diperolehnya APE sesuai dengan target yang ditentukan oleh tim. Dilihat dari respon yang diperoleh, potensi guru untuk menerapkan STEAM pada pendidikan anak usia dini sangat dimungkinkan. Memastikan bahwa setiap anak dibekali dengan pengetahuan dan keterampilan bidang STEAM sejak usia dini merupakan investasi yang menjanjikan yang mengarah pada pembengunan berkelanjutan di masa mendatang bagi suatu negara (Soylu, 2016). Kegiatan ini menjawab tantangan bahwa diperlukannya pengembangan profesional guru PAUD tentang pentingnya pendidikan STEAM, serta keterampilan pedagogik tentang disiplin STEAM (Margorini \& Rini, 2019).

\section{Kesimpulan}

Pelaksanaan proses pendampingan guru dalam memproduksi APE mencakup tiga tahapan utama yaitu launching, monitoring dan evaluating, yang memadukan aktivitas minds-on dan hands-on. Pada tahapan launching, guru menunjukkan pemahaman bagaimana pembelajaran yang konstruktif. Pada tahap monitoring, guru berproses untuk memproduksi dan menunjukkan hasil produk APE yang dibuat. Di tahap akhir, guru dapat menunjukkan performa implementasi pembelajaran dengan topik ekologi berbasis STEAM pada level yang baik, serta kesan secara umum positif terhadap peluang implementasi APE di kelas mereka.

Keterbatasan pada aktivitas PkM ini adalah tidak dilakukannya pendampingan implementasi secara langsung di kelas AUD, sehingga tidak dapat diketahui secara nyata kelemahan dan kelebihan dari APE yang sudah dibuat oleh guru. Rekomendasi dari kegiatan ini adalah dapat dilaksanakan kegiatan pendampingan implementasi pembelajaran STEAM untuk AUD dengan topik yang juga lebih beragam. Dengan demikian, diharapkan validasi praktis dan diseminasi model pembelajaran dengan pendekatan STEAM untuk anak usia dini dapat dilaksanakan secara meluas di masa mendatang.

\section{Ucapan Terima Kasih}

Terima kasih kami ucapkan kepada kelompok guru Pusat Kegiatan Gugus (PKG) SMART Kecamatan Temayang, Kabupaten Bojonegoro, Jawa Timur yang telah berpartisipasi aktif dalam kegiatan program pengabdian kepada masyarakat.

\section{Referensi}

Acharya, K. P. (2018). Hands-On, Minds-On And Hearts-On Activities In High School Science Teaching: A Comparison Between Public And Private Schools In Nepal. The Online Journal of New Horizons in Education, 8(2), 51-57.

Asoko, H. (2000). Learning to teach science in the primary school. In R. Millar, J. Leach, \& J. Osborne (Eds.), Improving Science Education: The contribution of research (1st ed., pp. 79-92). Open University Press.

Chaille, C., \& Britain, L. (2003). The Young Child As Scientist: A constructivist approach to early childhood science education (T. Mueller \& E. Tromblay (eds.); 3rd ed.). Pearson Education, Inc.

Dejarnette, N. K. (2018). Implementing STEAM in the Early Childhood Classroom. 3(3), 1-9.

Encyclopædia Britannica. (2020). Ecology. Encyclopædia Britannica, Inc (Artikel web). Diakses di: https://kids.britannica.com/kids/article/ecology/353082\#: :text=Ecology is the study of, in 
Imaduddin, M., Nihayati, L., Nugroho, T.W., Murti, W.B., Sa'adah, L., \& Kurniasari, D. Pendampingan ...

ecology are called ecologists.\&text=They also study how living, and water to stay alive.

Hofstein, A., Kipnis, M., \& Kind, P. (2008). Learning in and from science laboratories: Enhancing students' metacognition and argumentation skills. In C. L. Petroselli (Ed.), Science education issues and developments (pp. 59-94). Nova Science.

Imaduddin, M. (2017). Mendesain Ulang Pembelajaran Sains Anak Usia Dini yang Konstriktif melalui STEAM Project-Based Learning yang Bernuansa Islami. Proceeding AnCoMS 2017: 1st Annual Conference for Muslim Scholars, 950-958.

Imaduddin, M., \& Zuhaida, A. (2019). STREAMIN Model for the Next Generation of Science Education in Indonesia. Journal of Physics: Conference Series, 1233(1). https://doi.org/10.1088/1742$6596 / 1233 / 1 / 012096$

Kementerian Perindustrian Republik Indonesia. (2018). Making Indonesia 4.0. 1-8. https://kemenperin.go.id/download/18427

Margorini, S., \& Rini, R. Y. (2019). Penerapan Pembelajaran Berbasis Sains, Teknologi, Teknik Dan Matematika (STEM) Pada Anak Usia Dini: Kajian Literatur Terhadap Pandangan Abad 21. Prosiding Seminar Nasional Pendidikan FKIP, 2(1), 96-105.

Meli, P. (2020). Teaching and Learning in a Project-Based World (Artikel web). Diakses di: https://blog.100mentors.com/teaching-and-learning-pbl-4/

Montessori, M. (2013). Metode Montessori: Panduan Wajib untuk Guru dan Orang tua Didik PAUD (Pendidikan Anak Usia Dini) (G. L. Gutex (ed.)). Pustaka Pelajar.

Roberts, P. (2016). STEM in Early Childhood: How to keep it simple and fun. Early Childhood Australia National Conference 2016.

Soylu, Ş. (2016). STEM education in early childhood in turkey. Journal of Educational and Instructional Studies in the World, 6(1), 38-47.

Sudono, A. (2000). Sumber Belajar dan Alat Permainan (untuk Pendidikan Anak Usia Dini). Jakarta: PT Grasindo.

Sutaphan, S., \& Yuenyong, C. (2019). STEM Education Teaching approach: Inquiry from the Context Based. Journal of Physics: Conference Series, 1340(1). https://doi.org/10.1088/1742$6596 / 1340 / 1 / 012003$

Taylor, P. C. (2016). Why is a STEAM curriculum perspective crucial to the 21st century? Research Conference 2016, 89-93.

Diakses

di: https://research.acer.edu.au/cgi/viewcontent.cgi?article=1299\&context=research_conference

The OECD Programme for International Student Assessment. (2019). PISA 2018 Results (Volume I). 